\title{
Erratum
}

\section{THE EFFECTS OF IMMEDIATE AND DELAYED CORRECTIVE FEEDBACK ON L2 DEVELOPMENT - ERRATUM}

\section{Mengxia Fu}

\section{Shaofeng Li}

https://doi.org/10.1017/S0272263120000388, published online by Cambridge University Press, 9 October 2020.

In the original publication of this article, two headings appeared incorrectly. On the fifth page of the article, the first subheading under "Research on Feedback Timing" should read "Psychological Research." On the sixth page of the article, the first subheading under "SLA Research" should read "Online versus Offline Feedback."

The publisher apologizes for this error.

\section{REFERENCE}

Fu, M., \& Li, S. (2020) The effects of immediate and delayed corrective feedback on L2 development. Studies in Second Language Acquisition. Advance online publication. https://doi.org/10.1017/S0272263120000388 